\title{
Practical approach to diagnosis and management of primary immunodeficiency diseases
}

\author{
Rossouw TM, Theron AJ, Anderson R \\ Department of Immunology, University of Pretoria \\ *Corresponding author, email: theresa.rossouw@up.ac.za
}

\begin{abstract}
The occurrence of primary immunodeficiency diseases (PIDs) is low compared to that of immune-mediated disorders of autoimmune or atopic origin. However, progress in basic and clinical immunology over the past 3-4 decades has facilitated not only improved detection of PIDs, but has also created an awareness of an expanding spectrum of these conditions. Given that those who suffer from the most severe types of PID experience life-threatening microbial and viral infections usually from an early age, prompt recognition and definitive diagnosis enable implementation of appropriate prophylaxis and therapy, and, most importantly, corrective, immunorestoration using allogeneic haematopoietic stem cell transplantation. The purpose of the current review is therefore to alert family physicians to the presentation and types of PID that they may encounter in clinical practice, as well as to immunological screening procedures that can be undertaken to confirm or exclude the existence of the most common types of PID. This is followed by a consideration of prophylactic and therapeutic options and, finally, by a brief overview of gene therapy and gene-editing strategies that may offer alternatives to, or eventually replace, stem cell therapy.
\end{abstract}

Keywords: primary immunodeficiency diseases, diagnosis, clinical management, prophylaxis, haematopoietic stem cell transplantation, gene therapy

\section{Introduction}

Primary immunodeficiency diseases (PIDs) are stable, heritable, disorders almost all of which affect a single gene critically involved in promoting optimal immune competence. PIDs are distinct from acquired, secondary, transient or stable immunodeficiency states including, but not limited to, those of iatrogenic or viral (e.g. HIV in particular, influenza and measles viruses) aetiology, as well as those resulting from splenectomy or autoinflammatory disorders such as type 2 diabetes mellitus. More than 350 PIDs are now recognised. ${ }^{1}$ This is largely as a result of advances in sophisticated immunological/molecular technologies, which have enabled revealing insights into the functioning of the human immune system. Although the hallmark of a PID is increased susceptibility to recurrent microbial and viral infections, which are often poorly responsive to therapy, prolonged and life-threatening, these conditions may also predispose for development of allergic, autoimmune/ autoinflammatory and malignant disorders, particularly lymphomas in the case of the latter. ${ }^{2}$

PIDs are usually detected in early childhood, but, in some cases, diagnosis may only be made as late as the fifth decade, most notably in the case of common variable immunodeficiency $(C V I D)^{3}$ and, albeit to a lesser extent, other PIDs such as chronic granulomatous disease (CGD). ${ }^{4}$ Although it has been estimated that around six million people worldwide are afflicted with a
PID, even today in developed countries with the most advanced healthcare systems, the majority (70-90\%) of those living with a PID remain undiagnosed, while somewhat surprisingly in the United States of America the estimated average time taken from onset of symptoms to diagnosis of a PID is 12.4 years. ${ }^{4,5}$ This is of considerable concern given that early detection of a PID invariably, and often dramatically, improves quality of life and life expectancy through prompt implementation of appropriate medical intervention.

This review is focused on recent innovations in the diagnosis and management of the most commonly occurring PIDs and is intended as a guide for family practitioners, who, together with paediatricians, are often first to encounter a patient with a suspected PID. ${ }^{5}$

\section{Prevalence}

The reported prevalence of PIDs varies greatly by geographic region, ranging from 5.9/100 000 in the United Kingdom, ${ }^{6}$ $8-11 / 100000$ in France, ${ }^{7} 0.81-30.5 / 100000$ in the Middle East and North Africa region, ${ }^{8}$ and $126.8 / 100000$ in the United States, ${ }^{9}$ and is significantly influenced by the practice of consanguineous relationships, as well as accessibility to diagnostic services. No official figures exist for South Africa, but, according to the approach of Eley and Esser (2014), based on a mid-2018 population estimate of 57,4 million and assuming a prevalence similar to well-resourced settings, the total number of people 
with PIDs should range between 3387 and 72 783. However, fewer than 500 PID cases have been reported in South Africa. ${ }^{10}$

In South Africa, many factors mitigate against the early detection and treatment of PIDs. Together with possible underappreciation among medical practitioners of the prevalence and scope of these disorders, other impediments to recognition and diagnosis include limited access of many South Africans to sophisticated healthcare facilities, administration of Bacillus Calmette-Guérin (BCG) vaccine at birth, which may result in disseminated BCG infection and early death of those with the most severe PIDs and, lastly, the possible difficulty in prioritising PIDs in the setting of a high prevalence of HIV infection. There is therefore a need for increased awareness among healthcare practitioners of the spectrum of PIDs, their clinical presentation, and diagnostic pathways to follow.

\section{Characteristic clinical features}

It is estimated that the vast majority of PIDs are caused by antibody deficiency (accounting for approximately 60\%), combined immunodeficiency (CID), phagocytic disorders, and complement deficiencies. ${ }^{6}$ The most common presenting symptoms are infections that tend to be chronic, recurrent, are often caused by atypical or opportunistic pathogens, and resolve slowly or only partially with conventional therapy. Table I provides a summary of the common warning signs of PIDs, but it is estimated that the vast majority ( 90\%) of cases would present with three of these: a positive family history; need for intravenous antibiotics in the management of infections; and failure to thrive or stunting (height-for-age more than two standard deviations below the WHO Child Growth Standards median). ${ }^{11}$ A large number of PIDs has an X-linked recessive pattern of inheritance and therefore usually only affect boys. Common examples are $X$-linked agammaglobulinaemia, Wiskott-Aldrich syndrome, $X$-linked severe combined immunodeficiency (SCID), X-linked lymphoproliferative syndrome and the most common type of CGD.

Table I. Warning signs of PIDs

Family history Family history of PID or unexplained early death Failure to Failure of an infant to gain weight or grow normally

thrive

Infections Four (4) or more new ear infections within one year Two (2) or more serious sinus infections within one year

Two (2) or more pneumonias within one year

Disseminated BCG infection

Recurrent mycobacterial infections

Recurrent meningococcal infections

Two (2) or more deep-seated infections

Recurrent, deep skin or organ abscesses

Persistent oral or cutaneous fungal infection after one year of age

Pulmonary fungal infection (e.g. Pneumocystis jirovecii)

\section{Parasitic infection (e.g. Giardia lamblia)}

Autoimmune manifestations, especially in the very young

\begin{tabular}{|c|c|}
\hline \multirow{2}{*}{$\begin{array}{l}\text { Poor } \\
\text { response to } \\
\text { treatment }\end{array}$} & $\begin{array}{l}\text { Two (2) or more months on antibiotics with little } \\
\text { effect }\end{array}$ \\
\hline & Need for intravenous antibiotics to clear infections \\
\hline
\end{tabular}

Nine main groups of PIDs have been identified in the 2017 International Union of Immunological Societies'Phenotypic Classification for Primary Immunodeficiencies. ${ }^{14}$ These are:

- CID including conditions such as X-linked SCID and adenosine deaminase (ADA) deficiency.

- CID with associated or syndromic features including conditions such as Wiskott-Aldrich syndrome (WAS) and DiGeorge syndrome.

- Predominantly antibody deficiencies including the conditions CVID and selective IgA deficiency.

- Diseases of immune dysregulation including conditions such as Chediak-Higashi syndrome, X-linked lymphoproliferative syndrome (XLP), and haemophagocytic lymphohistiocytosis.

- Congenital defects of phagocyte number, function, or both including disorders such as leukocyte adhesion deficiency (LAD) and CGD.

- Defects in intrinsic and innate immunity including conditions such as chronic mucocutaneous candidiasis.

- Autoinflammatory disorders such as autoinflammatory disease associated with CGD.

- Complement deficiencies including deficiencies of components of the classical or alternative complement pathways e.g. C3, C5 or C6 deficiency, and C1 inhibitor deficiency.

- Phenocopies of PID. "A phenocopy is a condition where the phenotype of an individual is altered because of an environmental factor, and thus the individual appears to have an altered genotype, though in fact it does not."15 Examples include phenocopies associated with somatic mutations e.g. autoimmune lymphoproliferative syndrome (ALPSSFAG) and phenocopies associated with autoantibodies e.g. chronic mucocutaneous candidiasis due to IL-17 and/or IL-22 autoantibody. Importantly, IL-17 and IL-22 play key roles in mucosal immunity.

Table Il summarises the underlying immunological abnormalities, common infections and characteristic presentation of the most common PIDs. For readers who may have a particular interest in PIDs, a more comprehensive description of all nine groups of PID can be found as a supplementary table.

\section{Diagnostic approach}

Laboratory investigations of PID are guided by the medical history, clinical presentation and types of causative organism, and play a crucial role in referral of patients for immunological assessment. ${ }^{10}$ Screening tests are performed initially and provide a basis for more definitive follow-up investigations. A proposed progression of the laboratory investigation of a patient with a suspected PID is shown in Figure 1. Where applicable, the results should be compared to age-adjusted normal values, particularly in children. HIV infection should be excluded by way of PCR testing since antibody testing may be unreliable in patients with PIDs. ${ }^{16}$ 
Table II. Summary of the immunological abnormalities, mode of inheritance, common infections and characteristic presentation of the most common PIDs

\begin{tabular}{|c|c|c|c|c|}
\hline Deficiency & Name & $\begin{array}{l}\text { Immunological abnormalities and } \\
\text { mode of inheritance }\end{array}$ & Infections & Characteristic presentation \\
\hline 은 & SCID & $\begin{array}{l}\text { Heterogeneous group of disorders } \\
\text { with a common manifestation - most } \\
\text { commonly defective IL-2 receptor } \\
\text { expression on T-cells or ADA deficiency. } \\
\text { Severely depressed cell-mediated } \\
\text { immunity and antibody production. } \\
\text { Classified according to presence or } \\
\text { absence of B-cell and NK cell function. }\end{array}$ & \multirow{3}{*}{$\begin{array}{l}\text { Bacteria } \\
\text { (Streptococcus } \\
\text { pneumoniae, } \\
\text { Haemophilus } \\
\text { influenzae, } \\
\text { Staphylococcus } \\
\text { aureus), viruses (CMV), } \\
\text { fungi (Candida species, } \\
\text { Histoplasma species, } \\
\text { PJP) and protozoa. }\end{array}$} & $\begin{array}{l}\text { Present in first few months of life with } \\
\text { recurrent and often severe infections, } \\
\text { diarrhoea and failure to thrive. }\end{array}$ \\
\hline \multirow{2}{*}{ 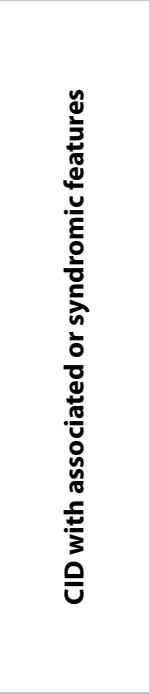 } & WAS & $\begin{array}{l}\text { X-linked recessive disease. } \\
\text { Decreased antibody production and } \\
\text { inability of T-cells to become polarised. } \\
\text { Defect in WAS protein. } \\
\text { Immunological features: } \\
\downarrow \text { IgM, } \uparrow \text { IgA and IgE, IgG variable. } \\
\text { Platelets are small and do not function } \\
\text { properly } \rightarrow \text { removed by spleen } \rightarrow \\
\text { thrombocytopaenia. }\end{array}$ & & $\begin{array}{l}\text { WAS triad. } \\
\text { W - Weeping skin lesions - eczema. } \\
\text { A - Absent platelets - } \\
\text { thrombocytopaenia - leading to } \\
\text { petechiae. } \\
\text { S - Severe immunodeficiency - (low IgM } \\
\text { and high IgA and IgE). }\end{array}$ \\
\hline & DiGeorge syndrome & $\begin{array}{l}\text { Autosomal dominant - 22q11.2 } \\
\text { deletion. } \\
\text { Thymic agenesis (failure of } \\
\text { development of } 3^{\text {rd }} \text { and } 4^{\text {th }} \text { pharyngeal } \\
\text { arches during the } 12^{\text {th }} \text { week of } \\
\text { gestation which give rise to the } \\
\text { parathyroid and thymus glands). } \\
\text { Varying degrees of severity. } \\
\text { Most severe form: failure to produce } \\
\text { T-cells } \rightarrow \text { abnormal cell-mediated } \\
\text { immunity and inability to produce } \\
\text { specific antibodies. }\end{array}$ & & $\begin{array}{l}\text { In severe form, infants who survive } \\
\text { neonatal period develop recurrent } \\
\text { viral, bacterial, fungal and protozoal } \\
\text { infections. } \\
\text { Characterised by cellular (T-cell) } \\
\text { deficiency, characteristic facies } \\
\text { (underdeveloped chin; eyes with } \\
\text { heavy eyelids; ears low set; rotated } \\
\text { back; defective upper portions of } \\
\text { earlobes, congenital heart disease and } \\
\text { hypocalcaemia). }\end{array}$ \\
\hline \multirow{7}{*}{ 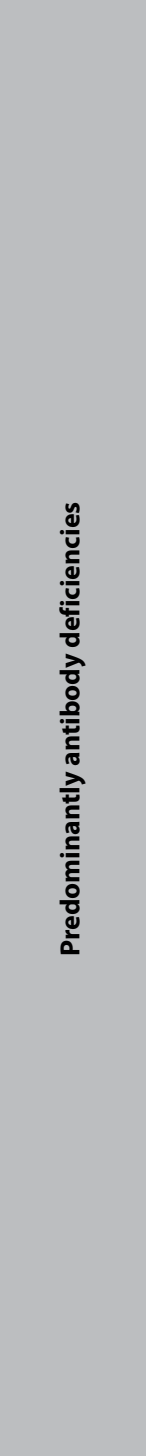 } & $\begin{array}{l}\text { X-linked } \\
\text { agammaglobulinaemia }\end{array}$ & $\begin{array}{l}\text { Defective gene. } \\
\text { B-cells absent. } \\
\text { B-cell maturation is arrested at the } \\
\text { pre-B-cell stage. }\end{array}$ & \multirow[t]{5}{*}{$\begin{array}{l}\text { Encapsulated bacteria } \\
\text { (S. pneumoniae, } \\
\text { H. influenzae), } \\
\text { mycoplasma, chronic } \\
\text { enterovirus infections. }\end{array}$} & $\begin{array}{l}\text { Sinopulmonary infections begin in } \\
\text { male infants ( }<1 \text { year) as maternal lgG } \\
\text { antibodies disappear. } \\
\text { Hypotrophic peripheral lymph nodes, } \\
\text { tonsils and adenoids. }\end{array}$ \\
\hline & $\begin{array}{l}\text { Transient } \\
\text { hypogammaglobulin- } \\
\text { aemia of infants }\end{array}$ & $\begin{array}{l}\text { Unsure aetiology. } \\
\text { Abnormalities of T-cell help or intrinsic } \\
\text { B-cell defect with abnormal antibody } \\
\text { responses. }\end{array}$ & & $\begin{array}{l}\text { Normal growth. } \\
\uparrow \text { Susceptibility to infection, esp. } \\
\text { premature babies. } \\
\text { Hypotrophic peripheral lymph nodes, } \\
\text { tonsils and adenoids. } \\
\text { Normal responses to protein } \\
\text { immunisations. } \\
\downarrow \text { Responses to polysaccharide and } \\
\text { conjugated polysaccharide antigens. }\end{array}$ \\
\hline & CVID & $\begin{array}{l}\text { Found in } \sim 1 / 25000 \text { persons. } \\
\text { Cause unknown. } \\
\downarrow \operatorname{lgG} \text { and } \lg A \text { or } \\
\downarrow \operatorname{lgG}, \lg A \text { and } \lg M \\
\text { T-cell defect. }\end{array}$ & & $\begin{array}{l}\text { Present at any age, commonly late } \\
\text { (20-30 years or older). } \\
\text { Triad of recurrent infections; } \\
\text { autoimmune phenomena - } \\
20 \% \text { (rheumatoid arthritis, } \\
\text { vitiligo, haemolytic anaemia, } \\
\text { thrombocytopaenia, neutropenia, } \\
\text { pyoderma gangrenosum, alopecia } \\
\text { areata/universalis); malignancy (B-cell } \\
\text { lymphomas). }\end{array}$ \\
\hline & $\begin{array}{l}\text { X-linked hyper-lgM } \\
\text { syndrome }\end{array}$ & $\begin{array}{l}\text { CD154 (CD40L) absent on T-cells. } \\
\text { Failure of B-cells to class switch. } \\
\text { Variable defect in T-cell and } \\
\text { macrophage effector function. }\end{array}$ & & $\begin{array}{l}\text { Highly susceptible to infection with } \\
\text { extracellular pathogens, but also } \\
\text { viruses, fungi and parasites. } \\
\text { Lymphoid hyperplasia and } \\
\text { splenomegaly. } \\
\text { Autoimmune disorders and } \\
\text { malignancies. }\end{array}$ \\
\hline & Selective IgA deficiency & $\begin{array}{l}\text { Most common PID (1/700). } \\
\text { Cause unknown. } \\
\text { B-cells present, but fail to switch to } \lg A \text {. }\end{array}$ & & $\begin{array}{l}\text { Majority asymptomatic, but some } \\
\text { develop recurrent sinopulmonary } \\
\text { infections. } \\
\text { Allergic conjunctivitis, urticaria and } \\
\text { asthma. } \\
\text { Various GIT diseases (e.g. food allergy). }\end{array}$ \\
\hline & $\begin{array}{l}\text { Selective deficiency } \\
\text { of } \lg G 2\end{array}$ & $\begin{array}{l}\text { B-cells present. } \\
\text { Do not produce } \lg G 2 \text {. } \\
\text { Can occur with } \lg A \text { deficiency. }\end{array}$ & $\begin{array}{l}\text { Susceptible to } S \text {. } \\
\text { pneumoniae and } \mathrm{H} \text {. } \\
\text { influenzae infections. }\end{array}$ & Sinopulmonary infections. \\
\hline & $\begin{array}{l}\text { Selective deficiency } \\
\text { of } \operatorname{lgG} 3\end{array}$ & $\begin{array}{l}\text { B-cells present. } \\
\text { Fail to produce lgG3. }\end{array}$ & $\begin{array}{l}\text { Diphtheria, tetanus } \\
\text { bacteria and } \\
\text { viruses. }\end{array}$ & $\begin{array}{l}\text { Prone to upper respiratory tract } \\
\text { infections. }\end{array}$ \\
\hline
\end{tabular}




\begin{tabular}{|c|c|c|c|c|}
\hline 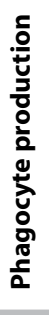 & (1) & $\begin{array}{l}\text { Origin unknown. } \\
\text { Can be inherited. } \\
\downarrow \text { Neutrophils every } 21 \text { days. }\end{array}$ & \multirow[t]{3}{*}{$\begin{array}{l}\text { Catalase+ bacteria e.g. } \\
\text { S. aureus, Burkholderia } \\
\text { cepacia, Serratia } \\
\text { marcescens, Nocardia } \\
\text { species, Escherichia } \\
\text { coli, Pseudomonas } \\
\text { aeruginosa, TB, NTM, } \\
\text { BCG and fungal } \\
\text { infections e.g. } \\
\text { Aspergillus fumigatus. }\end{array}$} & $\begin{array}{l}\text { Severe systemic bacterial infections } \\
\text { from early infancy. } \\
\text { Occasionally fungal infections. } \\
\text { Poorly responsive to antimicrobial } \\
\text { chemotherapy. } \\
\text { Life-threatening. } \\
\text { Infections during neutropenic periods. } \\
\text { Fever, malaise and mouth ulcers. }\end{array}$ \\
\hline \multirow{2}{*}{ 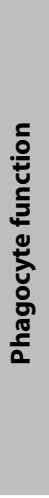 } & LAD & $\begin{array}{l}\text { LAD-1: absence of beta } 2 \text { integrin on } \\
\text { neutrophils. } \\
\text { LAD-2: absence of counter receptor to } \\
\text { E- and P-selectins. } \\
\text { Neutrophils cannot migrate out of the } \\
\text { circulation to sites of infection. } \\
\text { LAD-3: failure of the adhesive functions } \\
\text { of integrins on both leukocytes and } \\
\text { platelets. }\end{array}$ & & $\begin{array}{l}\text { Life-threatening bacterial infections. } \\
\text { LAD-3 can also present with a bleeding } \\
\text { disorder due to a failure of platelet } \\
\text { aggregation. }\end{array}$ \\
\hline & CGD & $\begin{array}{l}\text { Mutations in NADPH oxidase in } \\
\text { phagocytes. } \\
\text { Cannot produce superoxide, hydrogen } \\
\text { peroxide or hypochlorous acid, } \\
\text { therefore cannot kill pathogens. }\end{array}$ & & $\begin{array}{l}\text { Fever, malaise, weight loss. } \\
\text { Cutaneous abscesses and } \\
\text { lymphadenitis; recurrent impetigo; } \\
\text { hepatic (and perihepatic) abscesses; } \\
\text { osteomyelitis; perirectal abscesses; } \\
\text { granulomas. }\end{array}$ \\
\hline 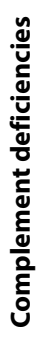 & $\begin{array}{l}\mathrm{C} 3 \\
\mathrm{C} 5 \\
\mathrm{C} 5 / \mathrm{C} 6 / \mathrm{C} 7 / \\
\text { C8/C9 } \\
\text { Deficiency in } \\
\text { assembling the cell } \\
\text { wall attack complex }\end{array}$ & $\begin{array}{l}\text { Genetic: autosomal recessive } \\
\text { X-linked - properdin deficiency. }\end{array}$ & $\begin{array}{l}\text { Early complement } \\
\text { deficiencies: } \\
\text { encapsulated } \\
\text { bacteria. } \\
\text { Terminal complement } \\
\text { deficiencies (C5-C9) } \\
\text { and properdin } \\
\text { deficiency: } \\
\text { bacterial infections, } \\
\text { specifically Neisseria } \\
\text { species. }\end{array}$ & $\begin{array}{l}\text { Early complement deficiencies: } \\
\text { sinopulmonary infections, auto-immune } \\
\text { manifestations (SLE). } \\
\text { Terminal C deficiencies: } \\
\text { meningococcal meningitis; gonorrhoea. }\end{array}$ \\
\hline
\end{tabular}

$\mathrm{CID}=$ combined immunodeficiencies; $\mathrm{SCID}=$ severe combined immunodeficiencies; $\mathrm{IL}=$ interleukin; $\mathrm{ADA}=$ adenosine deaminase; NK = natural killer cells; $\mathrm{CMV}=$ cytomegalovirus; $\mathrm{PJP}=\mathrm{Pneumocystis}$ jirovecii pneumonia; WAS = Wiskott-Aldrich syndrome; $l g=$ immunoglobulin; $C V I D=$ Common variable immunodeficiency; GIT = gastrointestinal tract; $T B=$ tuberculosis; $\mathrm{NTM}=$ non-tuberculous mycobacteria; $B C G=$ Bacillus Calmette-Guérin; $L A D=$ leukocyte adhesion deficiency; $C G D=$ chronic granulomatous disease; $N A D P H=$ nicotinamide adenine dinucleotide phosphate; $S L E=$ systemic lupus erythematosus

The investigation starts with a full blood count and differential, which may be very revealing even at this early stage of immunological assessment. ${ }^{10}$ For example, persistently low neutrophil or lymphocyte counts can indicate congenital neutropenia or SCID, respectively. The finding of lymphopaenia in a child with recurrent infection may indicate a primary abnormality of adaptive immunity, while neutrophilia that persists between infections occurs in patients with LAD. ${ }^{17}$ LAD is associated with abnormalities of leukocyte adhesion to vascular endothelium, resulting in the inability of neutrophils to emigrate from the bloodstream into sites of infection, hence the neutrophilia.

A blood smear can also be informative. The presence of giant cytoplasmic granules in leukocytes, or thrombocytopaenia and small platelet size are characteristic of the Chediak-Higashi syndrome and Wiskott-Aldrich syndrome, respectively. ${ }^{17}$

The most important initial screening test when an antibody deficiency is suspected, is quantitative determination of serum immunoglobulins ( $\lg G, \lg A$, $\lg M$ and $\lg E$ ) and $\lg G$ subclasses if necessary. ${ }^{16}$ IgG determination should preferably be undertaken when maternally-derived IgG has declined at about six months. Follow-up procedures include flow cytometric enumeration of circulating B cells, a procedure known as immunophenotyping. Flow cytometry is a procedure which combines laser and immunofluorescence technologies to enumerate different cell populations on the basis of size, granularity and expression of cell-specific proteins/glycoproteins known as cluster of differentiation (CD) markers, for example selective expression of CD19 on B-lymphocytes. Further testing may include the assessment of specific antibody responses to common vaccinations such as tetanus, diphtheria, pneumococcal and Haemophilus influenzae type B conjugate vaccines. Low levels of immunoglobulins and poor or absent antibody responses to immunisation, together with the absence of circulating B-cells in a male child, are consistent with the diagnosis of X-linked agammaglobulinaemia (Bruton's disease), which can be definitively diagnosed according to the absence of the enzyme Bruton's tyrosine kinase, which is essential for the development and maturation of B-cells.

Second-tier evaluation of suspected selective T-cell or combined T- and B-cell immunodeficiency disorders involves enumeration of the different types of circulating lymphocytes by flow cytometry, specifically total B-cells, T-cells $\left(\mathrm{CD}^{+}\right)$, T-cell subsets, these being helper T-cells (CD4+) and cytotoxic T-cells (CD8 $\left.{ }^{+}\right)$, and natural killer cells $\left(\mathrm{CD} 56^{+}\right)$. Immunophenotyping is particularly important in the diagnosis of SCID, as "the pattern of missing cell types helps to delineate the immunological defect present."16 If the numbers of T-cells are within the normal range, or if a dual abnormality of numbers and protective functions of T-cells is suspected, then additional tests of cell activation, proliferation and function such as cytokine production (IL-2, IL-12, IFN- $\gamma$ ) 
and receptor expression can be performed in vitro. Newborn screening for SCID using the TREC (T-cell receptor excision circle) assay has been employed in North America and Europe. Low TRECs as measured in dried blood spots by PCR, reflects T-cell lymphopaenia uncomplicated by the presence of B-lymphocytes or maternal T-cells. This test identifies newly-formed, immature T-cells which are absent in most forms of SCID, as well as conditions associated with very low numbers of T-lymphocytes. ${ }^{18}$ However, the test is costly and only available on request in South Africa. ${ }^{10}$

Having excluded abnormalities of cell numbers, either persistent or cyclical, as well as cell morphology, second-tier evaluation of suspected abnormalities of innate immunity, specifically those affecting neutrophils, should be directed at assays of the protective functions of phagocytic cells. The workup for LAD, of which there are three distinct types of this condition, involves assessment of the binding of neutrophils to activated vascular endothelium in vitro, as well as detection of the presence and activation status of neutrophil adhesion molecules using flow cytometry and other procedures. Various laboratory procedures can be used to confirm the diagnosis of CGD. These are usually based on assessment of the so-called "oxidative burst", a process by which neutrophils activated by bacterial pathogens generate a spectrum of antimicrobial reactive oxygen species. Absence of the phagocyte "oxidative burst" is the characteristic defect of CGD, resulting in failure to eradicate phagocytosed microbial pathogens and severe infection.

Abnormalities of the various complement systems can be detected by screening for total haemolytic complement activity, followed by measurement of the individual functional and regulatory components of the different pathways.
Genetic testing, if available, can be performed to identify causative mutations in affected genes. In this context, acquisition and application of next generation DNA sequencing technologies represents an ideal strategy to screen infants for PID-associated gene mutations, thereby improving diagnostic accuracy and efficacy and may be particularly useful in the detection of the less common types of PID. ${ }^{19}$

\section{Management - prevention of infection}

Several strategies for preventing infection should be employed, including routine immunisation, antimicrobial prophylaxis and immunoglobulin replacement therapy. In addition, general information regarding personal, hand and dental hygiene, avoidance of individuals with active infection, and immunisation of household contacts should be provided. ${ }^{20}$

\section{Immunisation}

As a rule, immunisation with live viral or bacterial vaccines is contraindicated in individuals with serious PIDs of T-cell, B-cell and phagocytic cell origin (Table III). Annual inactivated influenza immunisation is indicated, while measles, mumps, rubella (MMR), varicella, and hepatitis $A$ vaccination could also be undertaken, as well as administration of additional doses of inactivated pertussis-containing vaccine, only for older children. Patients with deficiencies of terminal complement components should receive meningococcal immunisation. Re-immunisation following bone marrow/stem cell transplantation is essential and should be directed by the transplant centre. Household and close contacts (older than six months of age) of PID patients should be encouraged to receive the annual inactivated influenza vaccine, as well as scheduled pertussis, pneumococcal, and MMR vaccines. Smallpox vaccine and the oral polio vaccine

\section{Screening procedures}

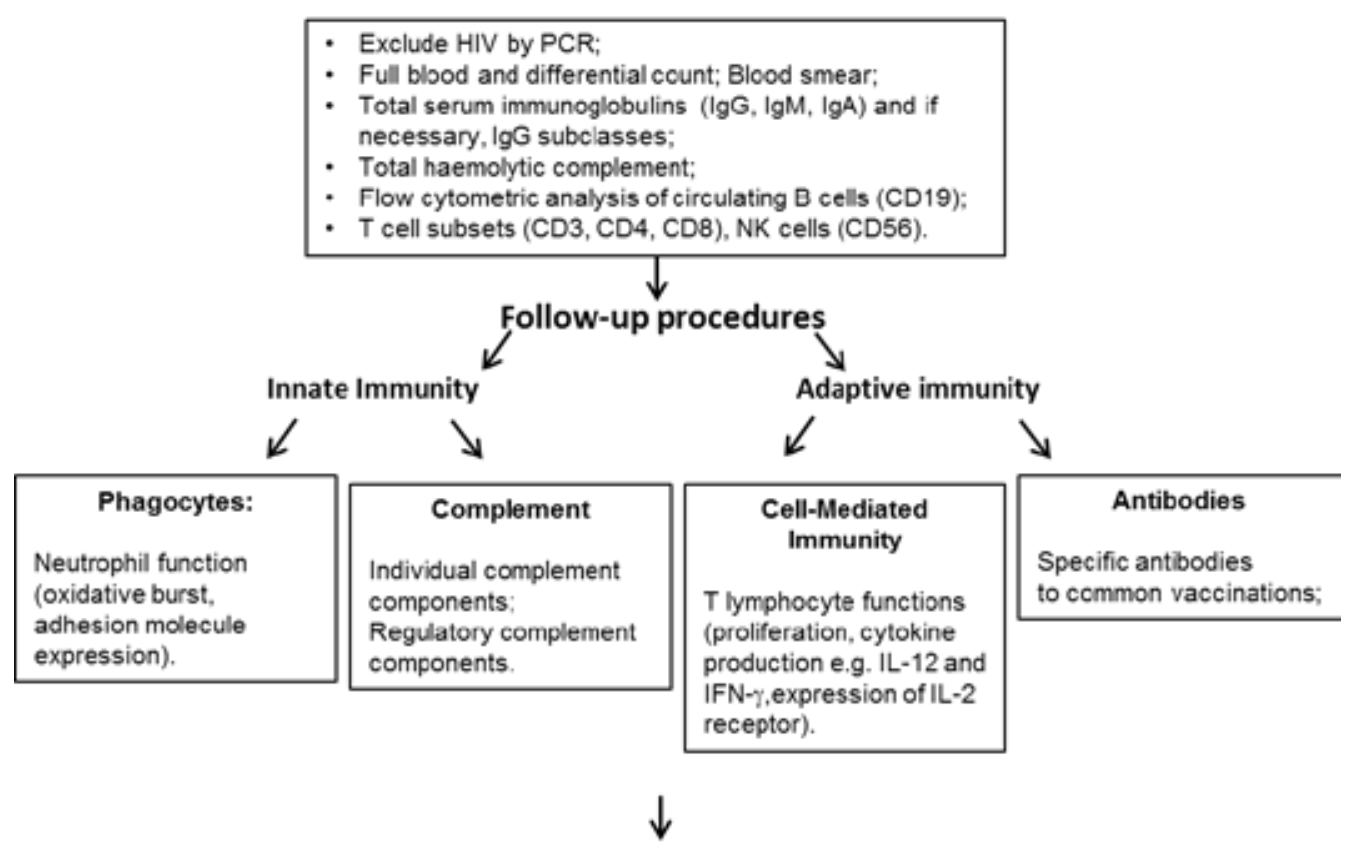

Additional tests

Molecular/genetic analysis if avalable

Figure 1. Diagnostic algorithm for PID 
Table II. Immunisations contraindicated in certain PIDs

\begin{tabular}{|c|c|}
\hline Condition & Vaccines contraindicated \\
\hline $\begin{array}{l}\text { Complete, cell-mediated deficiencies e.g. SCID, complete DiGeorge } \\
\text { syndrome }\end{array}$ & $\begin{array}{l}\text { All live vaccines. } \\
\text { All vaccines are probably ineffective, but pneumococcal and } H \text {. influenzae } \\
\text { type B vaccines are recommended. }\end{array}$ \\
\hline $\begin{array}{l}\text { Partial defects e.g. most patients with DiGeorge syndrome, } \\
\text { Wiskott-Aldrich syndrome, Ataxia telangiectasia }\end{array}$ & $\begin{array}{l}\text { Selected live vaccines: BCG, Ty21a Salmonella typhi vaccine, live attenuated } \\
\text { influenza vaccine, MMR, varicella, herpes zoster, oral polio vaccine, yellow } \\
\text { fever, smallpox and rotavirus. }\end{array}$ \\
\hline $\begin{array}{l}\text { Severe antibody deficiencies e.g. X-linked agammaglobulinaemia } \\
\text { and CVID }\end{array}$ & $\begin{array}{l}\text { Oral polio vaccine, smallpox, live attenuated influenza vaccine, Yellow } \\
\text { fever, most live bacterial vaccines; consider measles; no data for varicella or } \\
\text { rotavirus vaccines. }\end{array}$ \\
\hline Less severe antibody deficiencies e.g. IgA or IgG subclass deficiency & Oral polio vaccine (other live vaccines appear to be safe). \\
\hline Phagocytic disorders e.g. CGD, LAD, myeloperoxidase deficiency & Live-bacterial vaccines i.e. BCG and Ty21a Salmonella typhi vaccine. \\
\hline Defects affecting the interferon-gamma - IL-12 pathway & Live mycobacterial vaccines (only BCG). \\
\hline Complement deficiencies & None. \\
\hline
\end{tabular}

Adapted from Eley et al, $2014^{20}$

are, however, contraindicated since vaccine viruses may be transmitted to immunocompromised individuals. ${ }^{20}$

\section{Antimicrobial prophylaxis}

Preventive antimicrobial treatment is indicated for all patients with CID, terminal complement deficiencies, abnormal neutrophil numbers or function, and in patients with severe antibody deficiencies if immunoglobulin treatment is unable to control the frequency of recurrent infections. The antibiotic treatment of choice is trimethoprim-sulphamethoxazole $5 \mathrm{mg} / \mathrm{kg}$ (of TMP) once daily or phenoxymethylpenicillin $125 \mathrm{mg}$ twice daily ( $<5$ years) or $250 \mathrm{mg}$ twice daily ( $>5$ years) in patients with WAS following splenectomy or in patients with terminal complement deficiencies. Patients with CID require additional antifungal and antiviral treatment in the form of fluconazole $3 \mathrm{mg} / \mathrm{kg}$ once daily and acyclovir $20 \mathrm{mg} / \mathrm{kg} /$ dose, four times daily. Patients with CGD should receive itraconazole $100 \mathrm{mg}$ daily ( $<13$ years or $<50 \mathrm{~kg}$ ) or $200 \mathrm{mg}$ daily ( $\geq 13$ years or $\geq 50 \mathrm{~kg}$ ) or posaconazole if available, and recombinant interferon-gamma dosed $50 \mu \mathrm{g} / \mathrm{m}^{3}$ three times per week.

\section{Immunoglobulin replacement therapy}

Immunoglobulin replacement therapy is indicated for antibody deficiencies and CID in which quantitative or qualitative IgG deficiency occurs. The exception is selective $\lg A$ deficiency since commercially available products contain very low levels and where, although rare, anaphylactic reactions have been described in patients with circulating anti-lgA antibodies. The preferred route is intravenous administration (IVIG) at 3-4-week intervals at a starting dose of $400 \mathrm{mg}$ per $\mathrm{kg}$ for patients without chronic lung disease and $600 \mathrm{mg}$ per $\mathrm{kg}$ for those with bronchiectasis. IVIG reactions, manifesting with nausea, chills, headache, backache, malaise, fever, pruritis, and/ or tingling, occur in $5-15 \%$ of patients and can be managed by slowing or stopping the infusion for 15-30 minutes or by administering aspirin ( $15 \mathrm{mg} / \mathrm{kg} /$ dose, orally), ibuprofen (5 $\mathrm{mg} / \mathrm{kg} / \mathrm{dose}$, orally) or hydrocortisone $(6 \mathrm{mg} / \mathrm{kg} / \mathrm{dose}$, IV, maximum $100 \mathrm{mg}$ ) one hour before an IVIG infusion. IVIG does not carry any risk of HIV or hepatitis $B$ transmission, but since outbreaks of non- $A$, non- $B$ hepatitis, including hepatitis $C$, have been reported, alanine aminotransferase levels should be monitored at 3-6 monthly intervals to detect subclinical transmitted hepatitis. ${ }^{20}$ Subcutaneous infusions can be considered as a possible maintenance strategy and have been shown to be efficacious and well tolerated, with a reduced incidence of systemic adverse events. Subcutaneous IgG is administered more frequently (daily to weekly) at higher doses, starting at $100-150 \mathrm{mg} / \mathrm{kg}$ per week.

\section{Management - corrective therapy}

Currently, allogeneic (between genetically non-identical individuals) haematopoietic stem cell transplantation (HSCT) remains the cornerstone of the corrective therapy of patients with life-threatening PIDs. Other strategies which are gaining prominence, but which in most types of PID await refinement, include gene therapy and gene editing.

\section{Haematopoietic stem cell transplantation (HSCT)}

This corrective strategy is used in the most severe types of PID, most commonly, but not limited to, SCID, serious antibody deficiency syndromes, intrinsic disorders of phagocyte function, specifically CGD and LAD syndromes, and WAS. HSCT is also commonly used in the corrective therapy of various types of haematological malignancy. HSCT involves reconstitution of patients' bone marrow with HSCs derived from the bone marrow or peripheral blood of a histocompatibility-matched donor [histocompatibility leukocyte antigen (HLA) matching, which is a critical prerequisite, while $A B O$ blood group matching, although preferable, is not essential], usually a close family member, or identified through national and international bone marrow registries. HSCT is preceded by a procedure known as myeloablative conditioning. This involves administration of cytotoxic drugs, usually fludarabine, busulphan and/or cyclophosphamide, often in combination with anti-thymocyte globulin or with targeted radiation. This strategy is used to eliminate host $\mathrm{HSCs}$, thereby minimising rejection of donor HSCs, which occurs even in the setting of severe PIDs. Although a necessary prerequisite to successful HSCT, myeloablative conditioning does, however, pose the potential risk of severe infection, as does post-HSCT administration of immunosuppressive therapy, usually with 
cyclosporine, to prevent graft-versus-host disease mediated by donor-derived immunocompetent cells.

Factors which can affect the outcome of HSCT include the type of PID, the age of the patient, the intensity of prior myeloablative conditioning, and the degree of donor/recipient histocompatibility matching. Despite these limitations, the success of HSCT corrective therapy has improved considerably in recent times, due largely to: i) the increasing expansion of, as well as accessibility to bone marrow registries; ii) the refinement and increased sensitivity of HLA histocompatibility testing procedures; iii) establishment of cryopreservation facilities, which enables storage of viable HSCs for future clinical application; and iv) the availability of strategies which enable the harvesting of HSCs from blood, usually from cord blood, which is stem cell (SC)-enriched, or more commonly following administration of granulocyte colony-stimulating factor (G-CSF, Filgrastim) to potential donors to increase production and mobilisation of SCs. Another innovation with respect to improved outcome of HSCT is the development of reduced intensity conditioning regimens, which may be of particular relevance in the setting of PIDs.21,22 Currently in the United Kingdom, overall survival rates at three years after allogeneic HSCT corrective therapy of PIDs are close to $90 \% .6,23$ According to a very recent report, however, CGD may represent an exception. The authors of this study reported that four years after HSCT therapy for CGD, 12 of 24 patients had developed severe autoimmune disorders, including cytopaenia, neuropathy and thyroid disease. ${ }^{24}$

Currently, several centres in the South African private and public sectors offer allogeneic HSCT, mostly for the corrective therapy of haematological malignancies. Very recently, however, a clinical transplantation team at UCT has reported on successful immunorestoration in three patients with PIDs (2 with SCID) following HSCT using SCs isolated from blood. ${ }^{25}$

\section{Gene therapy for PIDs}

Because almost all PIDs are monogenic gene disorders, targeted gene therapy represents an ideal corrective strategy, which has attracted considerable interest and effort during the last decade. Gene therapy of PIDs is based on isolation of a patient's HSCs and replacement in vitro of the defective gene with a copy of the functional gene using viral vectors to achieve target cell penetration of DNA. Genotoxicity of viral vectors and the inherent technically demanding nature of this procedure have, however, limited its application in the corrective therapy in PIDs. To date, gene therapy has achieved greatest success in correcting the adenosine deaminase deficiency variant of SCID, but has been less effective in other types of PID, particularly CGD, in which only transient restoration of phagocyte antimicrobial function has been achieved. ${ }^{26,27}$

\section{Gene editing}

This is a very recent innovation in genetic engineering which, although not yet practised in the clinical setting of the corrective therapy of PIDs, nevertheless holds considerable promise. Of the several types of gene editing procedures currently under development and preclinical evaluation, a procedure known as CRISPR (Clustered regularly interspaced palindromic repeat) - Cas9 has gained particular prominence in the correction of monomeric gene abnormalities. Using a viral vector to achieve penetration of HSCs isolated from patients with PIDs or other monomeric gene disorders, this strategy enables targeted delivery of an endonuclease enzyme (Cas9) to the precise genomic site of the target mutated gene, which is then excised (by the endonuclease) and the mutation repaired. Substantial refinements are, however, required prior to application of this novel technology in the context of human disease ${ }^{28}$ which will have to be undertaken in association with precise, prior characterisation of the causative gene mutation.

\section{Referral}

Patient outcomes are largely determined by early recognition and referral to centres with appropriate expertise in the management of PIDs. Pre- and aftercare of patients receiving HSCT and gene therapy is critical and should be guided by an expert. Expertise is available in the private and public sector and practitioners can contact the National Health Laboratory Service Expert Committee on Immunology for guidance. The Standard Operating Procedure is available on Q-Pulse as IMM0394.

\section{Conclusion}

Family physicians are at the forefront of early recognition and diagnosis of PIDs. This necessitates a high level of awareness and vigilance, together with a discerning, systematic clinical and laboratory work-up in order to expedite accurate diagnosis at minimal cost and discomfort to the patient, as well as cost to public and private healthcare sector insurers.

\section{Disclosure of interest}

The authors report no conflicts of interest

\section{References}

1. Condino-Neto A, Espinosa-Rosales FJ. Changing the lives of people with primary immunodeficiencies (PI) with early testing and diagnosis. Front Immunol 2018;9:1439.

2. Mayor $\mathrm{PC}$, Eng $\mathrm{KH}$, Singel $\mathrm{KL}$, et al. Cancer in primary immunodeficiency diseases: Cancer incidence in the United States Immune Deficiency Network Registry. J Allergy Clin Immunol 2018;141(3):1028-35.

3. Cunningham-Rundles $C$. The many faces of common variable immunodeficiency. Hematology Am Soc Hematol Educ Program 2012;2012:301-5.

4. Schwenkenbecher $P$, Neyazi A, Donnerstag F, et al. Chronic granulomatous disease first diagnosed in adulthood presenting with spinal cord infection. Front Immunol 2018;9:1258.

5. Orange JS, Seeborg FO, Boyle M, et al. Family physician perspectives on primary immunodeficiency diseases. Front Med 2016;3:12.

6. Shillitoe B, Bangs C, Guzman D, et al. The United Kingdom Primary Immune Deficiency (UKPID) registry 2012 to 2017. Clin Exp Immunol 2018;192(3):284-91.

7. Mahlaoui $\mathrm{N}$, Jais JP, Brosselin $\mathrm{P}$, et al. Prevalence of primary immunodeficiencies in France is underestimated. J Allergy Clin Immunol 2017;140(6):1731-3.

8. Al-Mousa $\mathrm{H}, \mathrm{Al}$-Saud B. Primary immunodeficiency diseases in highly consanguineous populations from Middle East and North Africa: epidemiology, diagnosis, and care. Front Immunol 2017;8:678.

9. Rubin Z, Pappalardo A, Schwartz A, Antoon JW. Prevalence and outcomes of primary immunodeficiency in hospitalized children in the United States. J Allergy Clin Immunol Pract 2018; doi: 10.1016/j.jaip.2017.12.002 [Epub ahead of Print]. 
10. Eley B, Esser M. Investigation and management of primary immunodeficiency in South African children. S Afr Med J 2014;104(11):7304.

11. PID UK. Symptoms and diagnosis of PIDs. http://www.piduk.org/whatarepids/ symptomsanddiagnosis Accessed 20 Aug 2018.

12. Esser M. Diagnosis for Primary Immunodeficiency (PID) by accessing available resources in South Africa. Rare Diseases Conference, 2016. http://www.rarex. co.za/2016/wp-content/uploads/2016/10/RareX-2016-Thursday-20-October_ Monika-Esser-.pdf Accessed 16 Aug 2018.

13. Arkwright PD, Gennery AR. Ten warning signs of primary immunodeficiency: a new paradigm is needed for the 21st century. In"The Year in Human and Medical Genetics: Inborn Errors of Immunity I." Jean-Laurent Casanova, Mary Ellen Conley and Luigi Notarangelo, Eds. Ann. N.Y. Acad. Sci. 2011;1238:7-14

14. Bousfiha A, Jeddane L, Picard C, et al. The 2017 IUIS Phenotypic Classification for Primary Immunodeficiencies. J Clin Immunol 2018;38(1):129-143.

15. Low KB. Phenocopy. Encyclopedia of Genetics 2001;1446; doi: 10.1006/ rwgn.2001.0984. https://www.sciencedirect.com/science/article/pii/ B0122270800009848?via\%3Dihub Accessed 14 Aug 2018.

16. Locke BA, Dasu T, Verbsky JW. Laboratory diagnosis of primary immunodeficiencies. Clin Rev Allergy immunol 2014;46(2):154-68.

17. Alkhater SA. Approach to the child with recurrent infections. J Family Community Med 2009;16(3):77-82.

18. Immune Deficiency Foundation. Newborn Screening. Available from: https:// primaryimmune.org/treatment-information/newborn-screening Accessed 16 Aug 2018.

19. King J, Ludvigsson JF, Hammarström L. Newborn screening for primary immunodeficiency diseases: the past, the present and the future. Int J Neonatal Screen 2017;3(3):19. doi:10.3390/ijns3030019.
20. Eley B, Hendricks M, Davidson A, et al. Primary Immunodeficiency diseases (PIDs): diagnostic and treatment considerations for patients managed at Red Cross War Memorial Children's Hospital (RCWMCH). PID Guide, version 1.0, 6 August 2014. http://www.paediatrics.uct.ac.za/sites/default/files/image_tool/ images/38/1.5.10\%20PIDs-diagnostic\%20\%20treatment\%20considerations.pdf

21. Ikegame K, Imai K, Yamashita M, et al. Allogeneic stem cell transplantation for $X$-linked agammaglobulinemia using reduced intensity conditioning as a model of the reconstitution of humoral immunity. J Hematol Oncol 2016;9:9.

22. Osumi T, Tomizawa $D$, Kawai $T$, et al. A prospective study of allogeneic transplantation from unrelated donors for chronic granulomatous disease with target busulfan-based reduced-intensity conditioning. Bone Marrow Transplant 2018; doi: 10.1038/s41409-018-0271-9. [Epub ahead of print].

23. Fox TA, Chakraverty R, Burns $S$, et al. Successful outcome following allogeneic hematopoietic stem cell transplantation in adults with primary immunodeficiency. Blood 2018;131(8):917-31.

24. Yanir AD, Hanson IC, Shearer WT, et al. High incidence of autoimmune disease after hematopoietic stem cell transplantation for chronic granulomatous disease. Biol Blood Marrow Transplant 2018; doi: 10.1016/j.bbmt.2018.03.029. [Epub ahead of print].

25. van Eyssen A, Novitsky N, de Witt $P$, et al. Single-centre experience of allogeneic haemopoietic stem cell transplant in paediatric patients in Cape Town, South Africa. S Afr Med J 2017;107(3):232-8.

26. Xu X, Tailor CS, Grunebaum E. Gene therapy for primary immune deficiencies: a Canadian perspective. Allergy Asthma Clin Immunol 2017;13:14.

27. Stirnadel-Farrant $H$, Kudari M, Garman N, et al. Gene therapy in rare diseases: the benefits and challenges of developing a patient-centric registry for Strimvelis in ADA-SCID. Orphanet J Rare Dis 2018;13:49.

28. The Lancet. Genome editing: proceed with caution. Lancet 2018;392(10144):253. 